\title{
Runoff Changes Based on Dual Factors in the Upstream Area of Yongding River Basin
}

\author{
Lei Hou, Wenqi Peng*, Xiaodong Qu, Quchang Chen, Yicheng Fu, \\ Fei Dong, Haiping Zhang
}

State Key Laboratory of Simulation and Regulation of River Basin Water Cycle, China Institute of Water Resources and Hydropower Research, Beijing, P.R. China

Received: 4 December 2017

Accepted: 2 January 2018

\begin{abstract}
Over the last 5 decades, runoff from the upstream area of the Yongding River basin has greatly decreased because of changes in the climate and in the intensity of human activities. The Mann-Kendall rank correlation trend test, cumulative anomaly method, and double mass curve of precipitation and runoff were applied to analyse the hydrological sequence trends and altered features in the upstream area of the Yongding River during 1960-2010. The influences of climate change and human activities on changes in runoff were quantitatively assessed using a climate elasticity method based on the Budyko hypothesis. In this paper, the results showed that, on average, runoff in the 3 basins in the upstream area of the Yongding showed a significant $(99 \%$ confidence level) downward trend. We found that human activities were the main driving factors for the decline in annual runoff in the Yanghe River basin, Sanggan River basin, and upstream area of the Yongding River basin, accounting for $82.04 \%, 81.51 \%$, and $75.69 \%$ of the runoff reduction, respectively, during evaluation period I, and accounting for $77.94 \%, 72.73 \%$, and $73.37 \%$ of runoff reduction, respectively, during evaluation period II. However, the impact of climate variability on runoff gradually increased over time in the 3 basins.
\end{abstract}

Keywords: climate variability, human activities, upstream area of the Yongding River, runoff change

\section{Introduction}

In recent years, global climate change and human activity have had a considerable impact on hydrological cycles [1-3] and changed the temporal and spatial patterns of precipitation and evaporation [4]. Thus, the runoff from many rivers around the world has exhibited a significantly decreasing trend that greatly threatens global

*e-mail: pwq@iwhr.com water security [5-7]. Even worse, the high frequency of extreme weather events has led to extreme flooding and severe droughts throughout the world. Furthermore, human activities have changed water cycle dynamics directly by changing the underlying surface conditions (land use/cover change, water conservancy project construction, etc.) of watersheds. The Yongding River is a tributary of the Haihe River basin, and the Guanting Reservoir in the Yongding is one of the main water sources of Beijing. In recent decades, the attenuation of runoff from the Yongding (compared with 
1955-1980, the annual inflow of Guanting Reservoir has since decreased by $93 \%$ in 1981-2000) has seriously threatened water resource and ecological security and affected the water resource allocations of the Beijing and Haihe river basins. Therefore, quantitatively interpreting the driving factors of runoff attenuation in the upper reaches of the Yongding (above Guanting Reservoir) urgently needs to be completed, which will provide a scientific basis for the coordinated development and configuration of water resources for Beijing-TianjinHebei.

To understand the hydrological cycle and maintain the sustainable development of water and ecological resources, much attention has been given to distinguishing between the influence of climate change and human activities on changes in runoff. Previous reports have indicated that human activities have altered the water cycle and enhanced runoff loss. Researchers have utilized many methods to evaluate the contribution rates of the main influencing factors for runoff changes, and these studies have revealed that runoff changes involve the dual influences of climate change and human activities. The most commonly used methods of quantitative analysis of runoff change include quantitative evaluation methods and hydrological models. The quantitative evaluation method used in this study is based on the methods of the Budyko-based climatic elastic coefficient [8], multivariate regression [9], sensitivity analysis [10], water balance [11], double mass curve of runoff and precipitation [12], and slope change ratio of accumulative quantity (SCRAQ) [13]. The hydrological model method is used to assess the influence of climate and human activities on runoff using a runoff simulation [14]. Many researchers have conducted research on the Haihe River basin [15], the Yangtze River basin [16], the Yellow River basin [12], and the Wei River basin as well as watersheds in other countries [17]. Based on their findings, runoff changes involved the interaction of climate change and human activities, with human activities as the dominant factor. Hydrological modelling includes complicated physical mechanisms and can effectively evaluate the contributions from climate change and human activities over different time scales; however, hydrological models require a large amount of observational input data and produce uncertainties in calibration and validation [18]. Statistical methods are relatively simple to calculate but lack a physical mechanism. Recently, Budyko-based climate elasticity methods have been widely applied because they include not only simple calculations but also a basic physical mechanism; these methods have proven to be accurate and credible [19].

Runoff in the Yongding River basin has received a great deal of attention. For example, Ding et al. [20] analysed the reduction factors of runoff within the Yongding River basin and found that human activity was the main driving force. Wang [21] used GBHM model analysis to determine the influence of land use/cover change (increase) on Yongding River basin runoff (paddy fields, water, urban and built-up land, and unused land increased the watershed runoff yield, while dry land, forested land, and grassland decreased the watershed runoff yield). More importantly, pre-existing research has mainly focused on changes in annual runoff. However, there may be a specific influencing factor on runoff that lacks an accurate description. To better understand the effects of climate change and human activities on hydrological processes, a more detailed quantitative assessment is needed.

This paper combined the Mann-Kendall rank correlation trend test, cumulative anomaly method, double mass curve of precipitation and runoff, and Budyko-based climatic elastic coefficient to quantitatively evaluate the impacts of climate change and human activities on runoff in the upper basins of the Yongding River during 1960-2010. This study had the following objectives:

1) To statistically detect trends and abrupt change points in hydrological and climatic time series of the watershed.

2) To effectively separate the influential values of climate change and human activities on changes in runoff and to quantitatively calculate the contributions of the main influential factors.

3) To explore the main factors of human activities that affect runoff change.

This study provides methodologies and data references for international counterparts to study the impacts of climate change and human activities on changes in runoff in the upper basins of the Yongding River. This study also provides a new understanding to help with balancing the security of global water resources.

\section{Material and Methods}

\section{Study Area and Data Sources}

The Yongding River basin is one of the 7 major water systems in the Haihe River basin and is the northwest branch of the Haihe River. The Sanggan River and the Yanghe River are upstream of the Yongding River basin; both rivers flow through Guanting Reservoir. This paper focuses on the upstream area of the Yongding (above Guanting Reservoir), which covers an area of more than 43,000 $\mathrm{km}^{2}\left(111^{\circ} 58^{\prime}-116^{\circ} 22^{\prime} \mathrm{E}, 38^{\circ} 50^{\prime}-41^{\circ} 16^{\prime} \mathrm{N}\right)$, as the study area (Fig.1). The study area is in a semiarid, sub-humid monsoon climate zone, which is part of the cool continental climate. The multi-year average temperature is approximately $5 \cdot 1-7.1^{\circ} \mathrm{C}$, and multi-year average precipitation is approximately $400 \mathrm{~mm}$, which is approximately $80 \%$ of the total annual precipitation that occurs over 6-8 months [22]. The watershed's topography is mountainous, and the mountainous area accounts for $80 \%$ of the total area. The elevation in the study area decreases from northwest to southeast and ranges from 500-1,000 m.

Several data sets were utilized, including annual runoff data from 3 hydrological stations (Guanting Reservoir, Shixiali, and Xiangshuipu), covering 


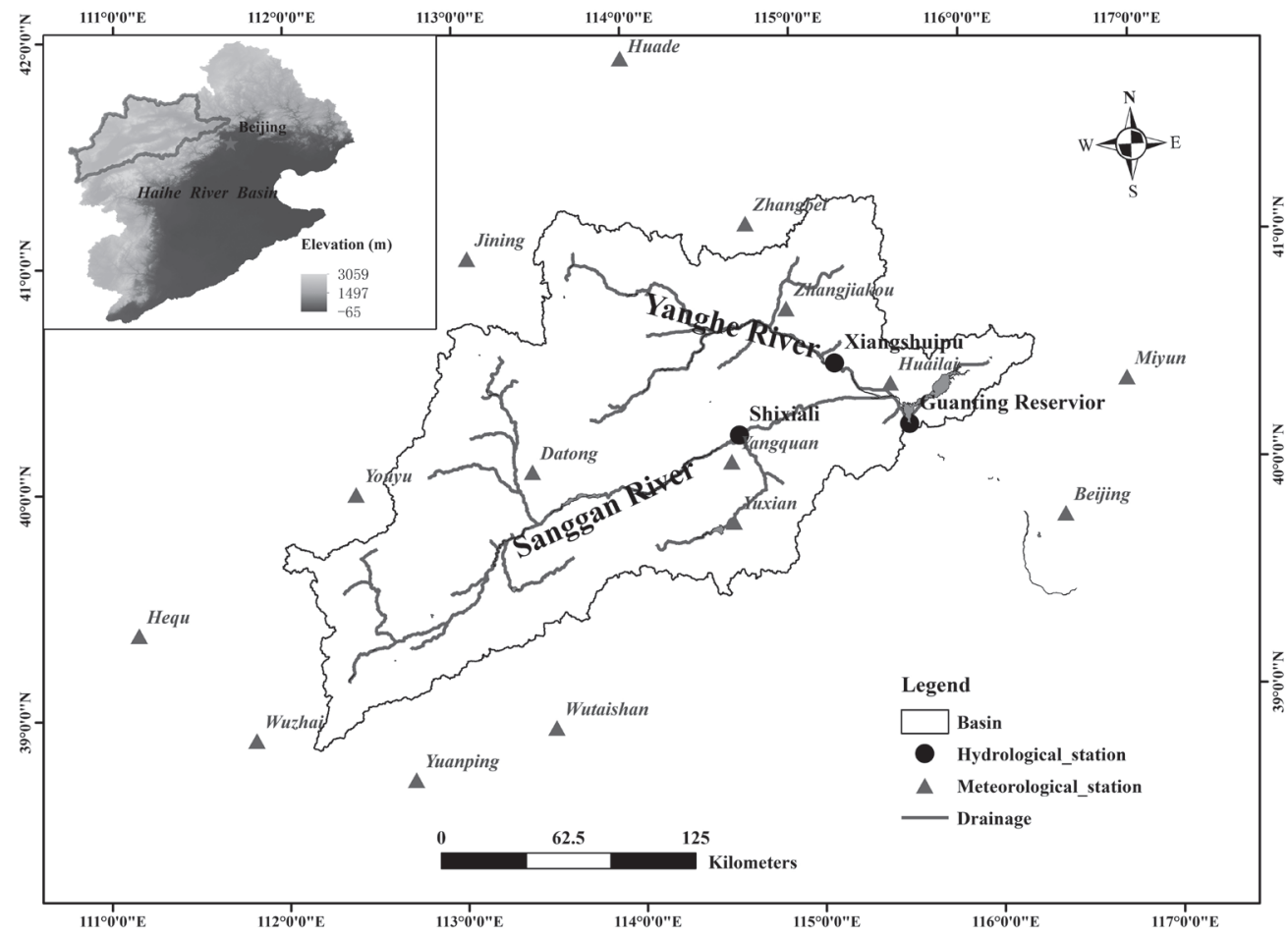

Fig. 1. Map of the upstream area of the Yongding River.

1960-2010, and meteorological data (monthly precipitation, maximum/minimum temperature, relative humidity, average wind speed, sunshine, etc.) from 15 stations (Beijing, Miyun, Huailai, Zhangjiakou, Zhangbei, Huade, Jining, Yuxian, Yangquan, Datong, Wutaishan, Youyu, Wuzhai, Hequ, and Yuanping). In this paper we used the Food and Agriculture Organization of the United Nations (FAO) recommended Penman Monteith method to calculate the potential evapotranspiration of the 15 meteorological stations. Then we used the spatial kriging interpolation method to determine the annual precipitation and potential evapotranspiration for all basins in the upstream area of the Yongding.

\section{Trend Test and Turning Point Analysis Method}

Mann-Kendall test. The Mann-Kendall test [23] was used to detect trends in the hydro-climatic series for this study. This method is one of the nonparametric statistical test methods that the World Meteorological Organization recommends and is widely used to assess the significance of monotonic trends in hydrological series [24-25], as it has the advantage of not following a distributional form for the data and has the same power as its parametric competitors. Furthermore, this method is simpler and is not affected by the interference of a few outliers.

Cumulative anomaly. The cumulative anomaly method is a statistical method where the trend of the curve can be determined using intuitive judgement of discrete data points. This method was used in this paper to detect streamflow variability in the study regions. The calculation process included the following: 1) calculate the annual runoff anomaly and 2) calculate the cumulative anomaly accumulation by time sequence. The process of change in the cumulative anomaly has accumulated over time. The periods with downward trends of cumulative anomaly (negative slope) represent intervals of lower streamflow than the average, while upward trends (positive slope) represent intervals of higher streamflow than the average. The cumulative anomaly series chart is used to detect abrupt change points in runoff series. A sudden change in the direction of the cumulative

Table 1. Hydroclimatic characteristics of the studied basin in the upstream area of the Yongding River.

\begin{tabular}{|c|c|c|c|c|c|}
\hline \multirow{2}{*}{ Basin } & \multirow{2}{*}{ Gauging station } & \multirow{2}{*}{$\begin{array}{c}\text { Drainage area } \\
\left(\mathrm{km}^{2}\right)\end{array}$} & \multicolumn{3}{|c|}{ Long-term mean value (1960-2010) } \\
\cline { 4 - 6 } & & & $\begin{array}{c}\text { Annual P } \\
(\mathrm{mm})\end{array}$ & $\begin{array}{c}\text { Annual E } \\
(\mathrm{mm})\end{array}$ & $\begin{array}{c}\text { Annual } \mathrm{R} \\
\mathrm{mm})\end{array}$ \\
\hline Upstream of Yongding River & Guanting Reservoir & 42,500 & 428.97 & $1,128.69$ & 15.00 \\
\hline Sanggan & Shixiali & 23,944 & 437.96 & $1,097.06$ & 13.75 \\
\hline Yanghe & Xiangshuipu & 14,507 & 409.17 & $1,151.60$ & 20.55 \\
\hline
\end{tabular}


anomaly indicates a sudden shift in the average. A period where the cumulative anomaly chart follows a relatively straight path indicates a period where the average does not change.

Double mass curve (DMC): The double mass curve is a common method to analyse hydro-climatic series. This method gradually accumulates two variables according to the same length of time, with one variable as the abscissa and another variable as the ordinate. The DMC between precipitation and runoff is a common method to determine the change trend of runoff. In this study, the DMC between precipitation and runoff was used as a secondary confirmation of the change points when human activities imposed the influences on the river. The turning point of the DMC can be used as the basis of analysis of variable phase change.

\section{Quantitative Assessment of the Effects of Climate Change and Human Activities on Runoff Change}

\section{Climate Elasticity Based on the Budyko Hypothesis}

For a given watershed, the long-term water balance equation can be simplified to the following:

$$
R=P-E_{a}+\Delta S
$$

...where $P$ is precipitation (mm), $R$ is runoff depth $(\mathrm{mm})$, $E_{a}$ is actual evapotranspiration $(\mathrm{mm})$, and $\Delta S$ is the change in water storage in the watershed, which can be negligible $(\Delta S=0)$ over long periods (e.g., 5-10 years) .

Budyko [26] assumed the ratio of mean annual actual evapotranspiration to the mean annual precipitation $\left[E_{a} / P\right]$ as a function of the ratio of the mean annual potential evapotranspiration to the mean annual precipitation $\left[E_{a} / P\right]$ and other watershed properties. $E_{0} / P$ is an aridity index, and the whole relational assumption can be expressed as,

$$
E_{a}=P F(\phi)
$$

To date, multiple mathematical Budyko-type hypotheses have been developed to describe the Budyko framework [26-31]. The Budyko-type equations can be divided into 2 categories. The first 4 equations are nonparametric (i.e., do not require any parameters during the calculation) and establish the empirical model between the precipitation and thermal balance model to estimate regional evapotranspiration. The last 2 equations have a single parameter, which gives them greater flexibility than the nonparametric equations, and they establish the evaporation area domain estimation model with a watershed underlying surface parameter adjustment [32]. The last 2 equations were shown to be virtually identical, and the Zhang equation is validated by more than 250 river basins, making the results of that study more practical; thus, in this study, the Zhang equation was used [31]:

$$
\begin{gathered}
F(\phi)=(1+\omega \phi) /\left(1+\omega \phi+\phi^{-1}\right) \\
F^{\prime}(\phi)=\left(2 \omega / \phi+1 / \phi^{2}\right) /(1+\omega \phi+1 / \phi)^{2}
\end{gathered}
$$

...where $\omega$ is a coefficient related to vegetation type. Zhang et al. [31] studied more than 250 river basins, and the results show that when the basin is a priority within the forest, $\omega=2.0$, and when the basin is a priority within the grass, $\omega=1.5$. The land use/cover type of the study area is complex, so it is difficult to apply the $\omega$ value, which is recommended by Zhang. In this paper, the parameter is calibrated by comparing long-term annual AET calculated by using Zhang's curve and the water balance equation (WBE).

Schaake [33] was the first to propose the climate elasticity method to estimate the impact of climate change on runoff. Although climate variability and human activities interact with each other, for a small basin, climate variability is mainly controlled by external forces. We assumed that precipitation $P$ and potential evaporation $E_{0}$ are independent variables at the watershed scale. Based on the climate elasticity of runoff ( $\left.\varepsilon=\frac{\partial R / R}{\partial X / X}\right)$, the change in runoff caused by climate change can be expressed as follows:

$$
\Delta R_{C}=\Delta R_{P}+\Delta R_{E_{0}}=\varepsilon_{P} \frac{\Delta P}{P} R+\varepsilon_{E_{0}} \frac{\Delta E_{0}}{E_{0}} R
$$

...where $\varepsilon_{P}$ is the runoff elasticity to precipitation and $\varepsilon_{E_{0}}$ is the runoff elasticity to potential evapotranspiration, which can be calculated as:

$$
\varepsilon_{P}=1+\frac{\phi F^{\prime}(\phi)}{1-F(\phi)}, \varepsilon_{P}+\varepsilon_{E_{0}}=1
$$

...where $P, E_{0}$, and $R$ are long-term annual average precipitation, potential evapotranspiration, and runoff, respectively. Precipitation elasticity $\left(\varepsilon_{p}\right)$ and potential evapotranspiration elasticity $\left(\varepsilon_{E_{0}}\right)$ can be determined, allowing the runoff change caused by climate change $\left(\Delta R_{C}\right)$ to be calculated, and thus the contribution of climate change can be assessed.

\section{Attribution Analysis of Runoff Changes}

In the basin, we assume that the impact of climate change and human activities on runoff were independent and that the runoff changes were affected by climate change and human activities; therefore, runoff depth $(R)$ can be expressed as the function of climate characteristics $(C)$ and human activities $(H)$ :

$$
R=f(C, H)
$$



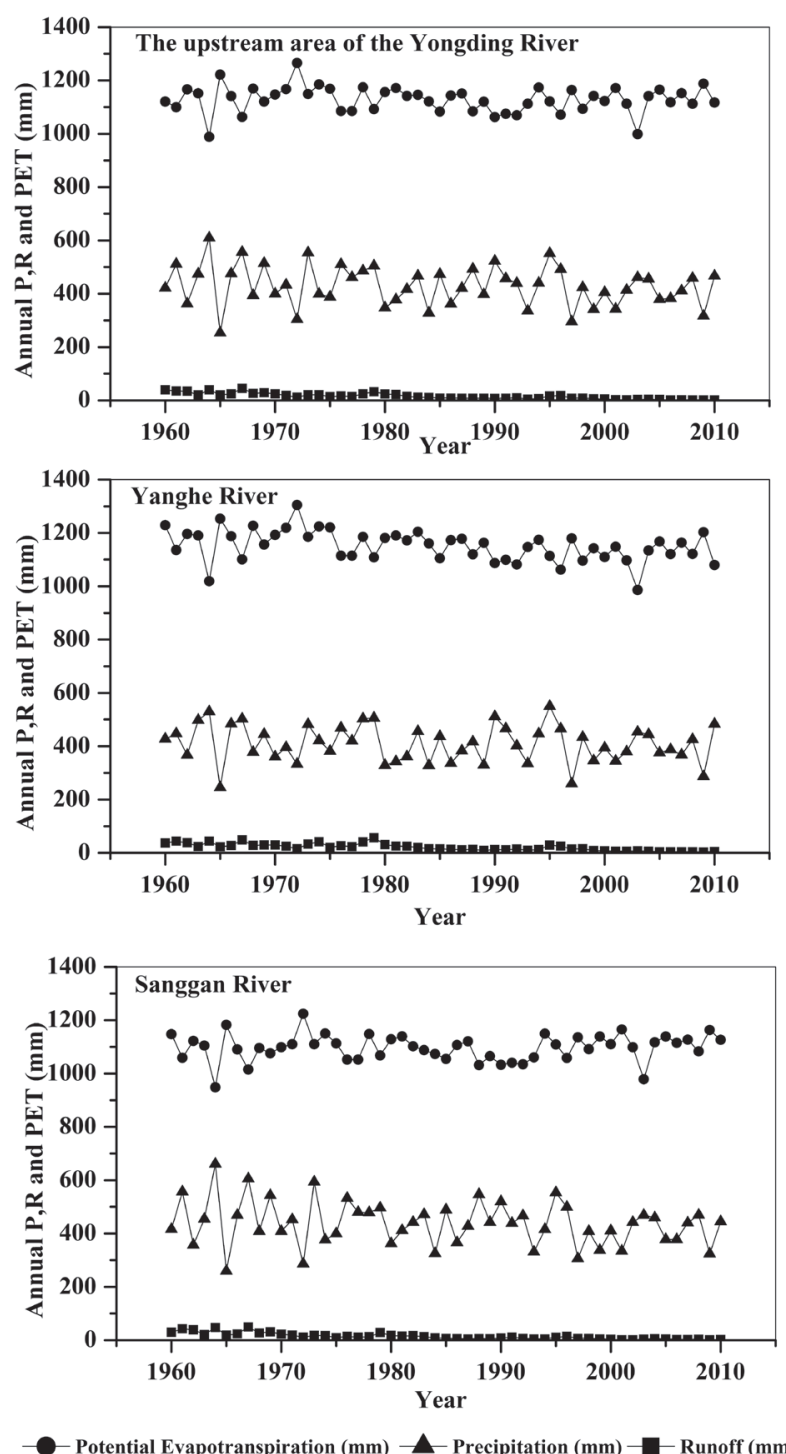

Fig. 2. Long-term variations in precipitation $(\mathrm{P})$, potential evapotranspiration (PET), and runoff (R) series in the 3 basins of the Yongding River basin.

On the basis of equation (1), the runoff change caused by climate change and human activities can be expressed as:

$$
\begin{gathered}
\Delta R=\Delta R_{C}+\Delta R_{H} \\
\eta_{C}=\frac{\Delta R_{C}}{\Delta R} \times 100 \% \\
\eta_{H}=\frac{\Delta R_{H}}{\Delta R} \times 100 \%
\end{gathered}
$$

...where $\Delta R_{C}$ and $\Delta R_{H}$ represent the runoff variation caused by climate change and human activities, respectively. $\Delta R=R_{1}^{a b c}-R_{2}^{a b c}$, where $R_{1}^{a b c}$ and $R_{2}^{a b c}$ are the measured average runoff in the baseline period and the variation period, respectively. $\eta_{C}$ and $\eta_{H}$ are the percentage contributions of climate-induced and human activity-induced runoff changes.

\section{Results and Discussion}

Trends and Change Point Analysis for Hydro-Climatic Series

The observed annual precipitation, runoff, and calculated PET series for the 3 basins during 1960-2010 are presented in Fig. 2.

All the basins exhibited a large variation in their runoff, whereas the changes in precipitation and PET appear to be more stationary. Table 2 shows the statistical results of trends in precipitation, runoff, and PET based on the Mann-Kendall test. The annual precipitation in all the basins decreased, and the statistically significant trends can be identified for the upstream area of the Yongding River and Sanggan River basins. At the same time, only the Yanghe River basin was dominated by significant trends (with a confidence level of 99\%) in PET. As opposed to precipitation and PET, which have no clear trends, the annual runoff in all 3 basins presented significant negative trends with remarkable negative trends (with a confidence level of 99\%), and the slope of runoff changes were 0.66 (the upstream area of the Yongding River), 0.66 (Sanggan River), and 0.71 (Yanghe

\begin{tabular}{|c|c|c|c|c|c|c|c|c|c|c|}
\hline \multirow[b]{2}{*}{ Basin } & \multirow{2}{*}{$\begin{array}{l}\text { Gauging } \\
\text { station }\end{array}$} & \multicolumn{3}{|c|}{ Annual streamflow } & \multicolumn{3}{|c|}{ Annual precipitation } & \multicolumn{3}{|c|}{ Annual PET } \\
\hline & & z-test & $\begin{array}{l}\text { signifi- } \\
\text { cance }\end{array}$ & $\begin{array}{l}\text { Slope } \\
(\mathrm{mm} / \mathrm{a})\end{array}$ & z-test & $\begin{array}{l}\text { signifi- } \\
\text { cance }\end{array}$ & $\begin{array}{l}\text { Slope } \\
(\mathrm{mm} / \mathrm{a})\end{array}$ & z-test & $\begin{array}{l}\text { signifi- } \\
\text { cance }\end{array}$ & $\begin{array}{l}\text { Slope } \\
(\mathrm{mm} / \mathrm{a})\end{array}$ \\
\hline $\begin{array}{l}\text { Upstream of } \\
\text { Yongding } \\
\text { River }\end{array}$ & $\begin{array}{l}\text { Guanting } \\
\text { Reservoir }\end{array}$ & -7.61 & $* * *$ & -0.66 & -1.37 & $*$ & -0.97 & -0.91 & ns & -0.37 \\
\hline $\begin{array}{c}\text { Sanggan } \\
\text { River }\end{array}$ & Shixiali & -7.50 & $* * *$ & -0.66 & -1.31 & $*$ & -1.24 & 0.69 & ns & 0.25 \\
\hline $\begin{array}{l}\text { Yanghe } \\
\text { River }\end{array}$ & Xiangshuipu & -6.88 & $* * *$ & -0.71 & -1.04 & ns & -0.71 & -3.39 & $* * *$ & -1.64 \\
\hline
\end{tabular}
River).

Table 2. Summary of the trend analysis for annual streamflow, precipitation, and potential evapotranspiration by the Mann-Kendall test.

$* * *, * *$ and $*$ indicate confidence levels of $99 \%, 95 \%$, and $90 \%$, respectively; ns indicates a confidence level under $90 \%$ 
We used the cumulative anomaly method to detect the change points in the runoff series. The results from the cumulative anomaly method (Fig. 3) present significant change points in 1981 for the upstream area of the Yongding River, in 1971 and 1982 for the Sanggan River basin, and in 1982 for the Yanghe River basin. For the upstream area of the Yongding River basin, the turning point in 1982 for the runoff record was also found by Pettitt's test method in the literature [20]. The double cumulative curve method was also employed to investigate the change points of the runoff series. Fig. 3 shows the double cumulative curve of annual precipitation-runoff over the 3 basins. The relationships between precipitation and runoff are presented in 3 nearly straight lines with different slopes before and after 1971 and 1982 for the Sanggan River basin, before and after 1982 and 1997 for the Yanghe River basin, and before and after 1981 and 1999 for the upstream area of the Yongding River basin, indicating that there may be an abrupt change in the runoff series. Overall, the change points identified for annual runoff occurred primarily in the early 1980s and late 1990s. Therefore, the study period for all the basins can be divided into 3 periods (i.e., baseline period, evaluation period I, and evaluation period II) based on the change points (Table 3). Relative to the baseline period, the differences in the double cumulative curve slope of annual precipitation-runoff for the 2 evaluation periods (Fig. 4) were investigated to further understand the effects of climate and other factors on runoff during the 2 evaluation periods.

\section{Effects of Climate Variability and Human Activities on Runoff}

The calibrated $\omega$ value, the runoff elasticity to precipitation $\varepsilon_{p}$, and the runoff elasticity to potential evapotranspiration $\varepsilon_{E_{0}}$ are shown in Table 4. The

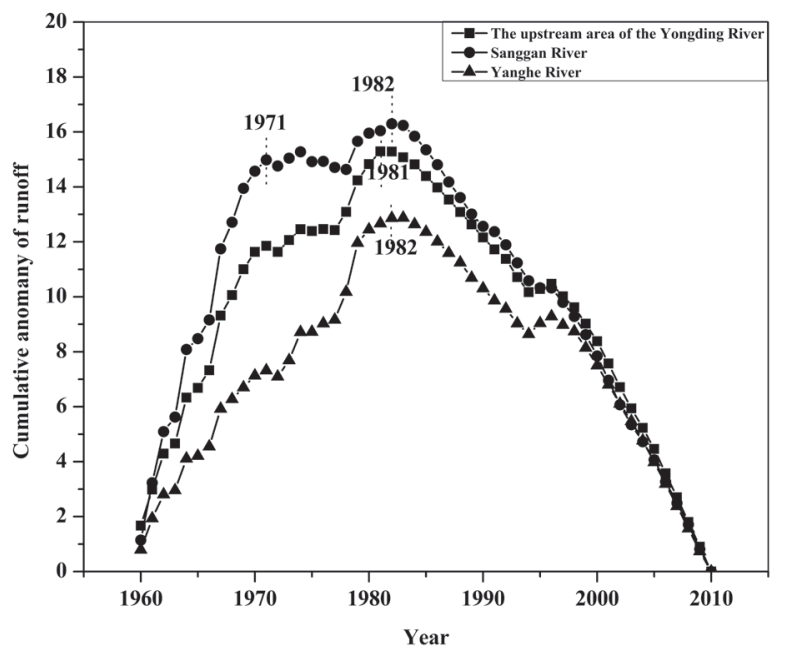

Fig. 3. Change points of the runoff series during the period 1960-2010 detected by the cumulative anomaly method for 3 basins of the upstream area of the Yongding River basin. comparison of actual annual evapotranspiration (AET) calculated by Zhang's curve and water balance equation (WBE) for the 3 basins is shown in Fig. 5. The $R^{2}$ values are greater than 0.98 . Generally, all the scatter points calculated by WBE and simulated by Zhang's curve are concentrated around the 1:1 line (Fig. 5),
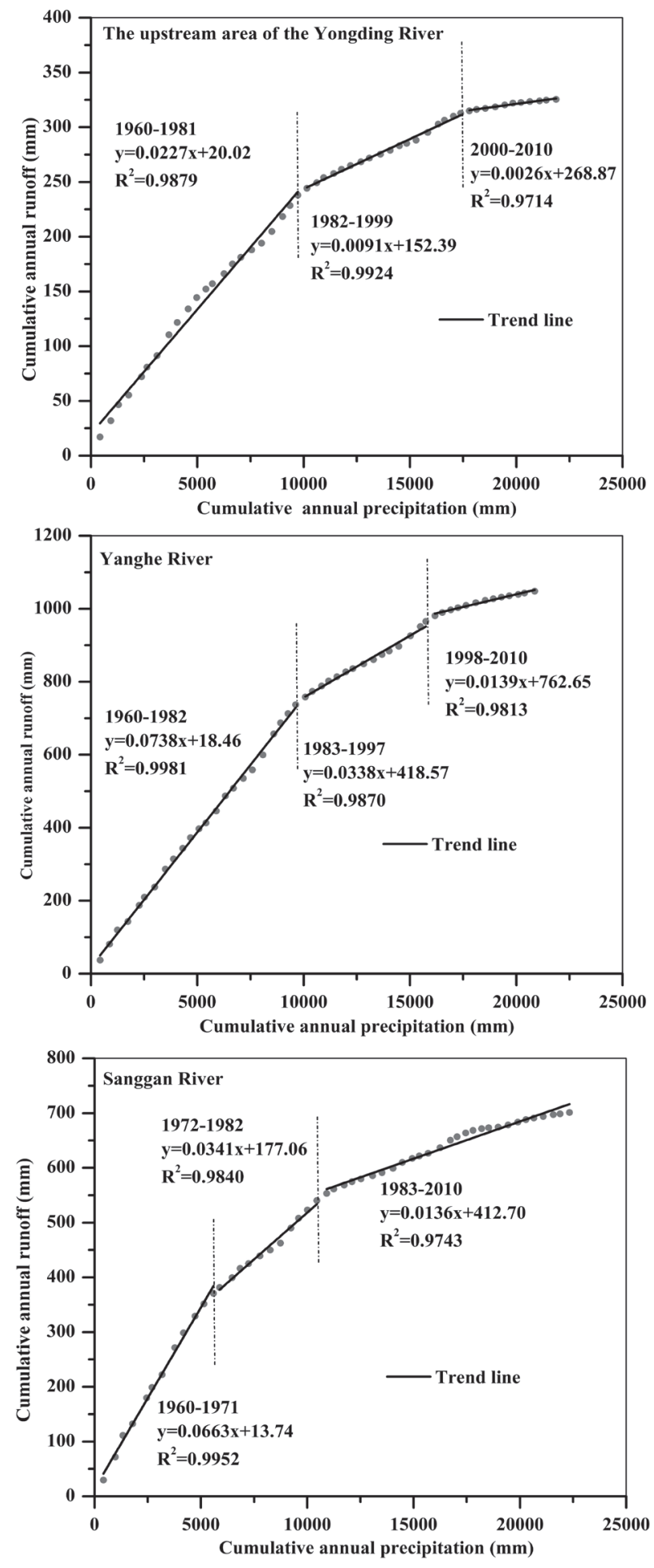

Fig. 4. Double mass curve of the annual precipitation and runoff for 3 basins of the upstream area of the Yongding River basin. 
Table 3. Summary of the annual runoff change point analysis.

\begin{tabular}{|c|c|c|c|c|c|c|}
\hline \multirow{2}{*}{ Basin } & \multicolumn{2}{|c|}{ Baseline period } & \multicolumn{2}{|c|}{ Evaluation period I } & \multicolumn{2}{|c|}{ Evaluation period II } \\
\hline & Year & Mean $(\mathrm{mm})$ & Year & Mean (mm) & Year & Mean (mm) \\
\hline $\begin{array}{l}\text { The upstream area } \\
\text { of the Yongding River }\end{array}$ & $1960-1981$ & 25.44 & 1982-1999 & 9.78 & $2000-2010$ & 2.70 \\
\hline Sanggan River & $1960-1971$ & 30.91 & $1972-1982$ & 15.39 & $1983-2010$ & 5.75 \\
\hline Yanghe River & 1960-1982 & 32.05 & 1982-1997 & 15.23 & $1998-2010$ & 6.36 \\
\hline
\end{tabular}

and all the $\omega$ values are between 0.5 and 2 (Table 4), indicating that the results simulated by Zhang's curve are realistic and acceptable. Taking the Yanghe River basin as an example, the precipitation elasticity $\left(\varepsilon_{p}\right)$ and potential evapotranspiration elasticity $\left(\varepsilon_{E_{0}}\right)$ (Table 4) reveal that if precipitation decreases by $10 \%$, runoff will decrease by $27.3 \%$, and if potential evapotranspiration decreases by $10 \%$, runoff will increase by $17.3 \%$. We found that changes in runoff were more sensitive to variations in precipitation than variations in potential evapotranspiration within the study area.

The quantitative effect derived from the climate elasticity method and based on the Budyko hypothesis is shown in Table 5. For all the basins, the climate elasticity method provided quantitative results for the changes in runoff for the 2 evaluation periods based on the baseline period and due to climate variability and human activities. Human activities were the dominant factors for runoff change across all the basins. Within the 3 basins, the proportions of human activities that affected runoff change during evaluation period II were greater than those of human activities that affected runoff change during evaluation period I, which indicated that the influence of human activities on runoff change was waning and that the impact of climate variability on runoff change was gradually increasing.

\section{The Influencing Factors of Human Activities on Runoff Change}

\section{Impacts of Land Use/Cover on Hydrological Change}

The upstream area of the Yongding River basin is experiencing large soil and water losses in the Haihe

Table 4. Model parameters for precipitation and potential evapotranspiration elasticity for the climate elasticity method based on the Budyko hypothesis.

\begin{tabular}{|c|c|c|c|}
\hline \multirow{2}{*}{ Basin } & \multirow{2}{*}{$w$} & \multicolumn{2}{|c|}{ Climate elasticity } \\
\cline { 3 - 4 } & & $\varepsilon_{P}$ & $\varepsilon_{E_{0}}$ \\
\hline $\begin{array}{c}\text { Upstream area of the } \\
\text { Yongding River }\end{array}$ & 1.90 & 2.72 & -1.72 \\
\hline Sanggan River & 1.95 & 2.71 & -1.71 \\
\hline Yanghe River & 1.80 & 2.73 & -1.73 \\
\hline
\end{tabular}
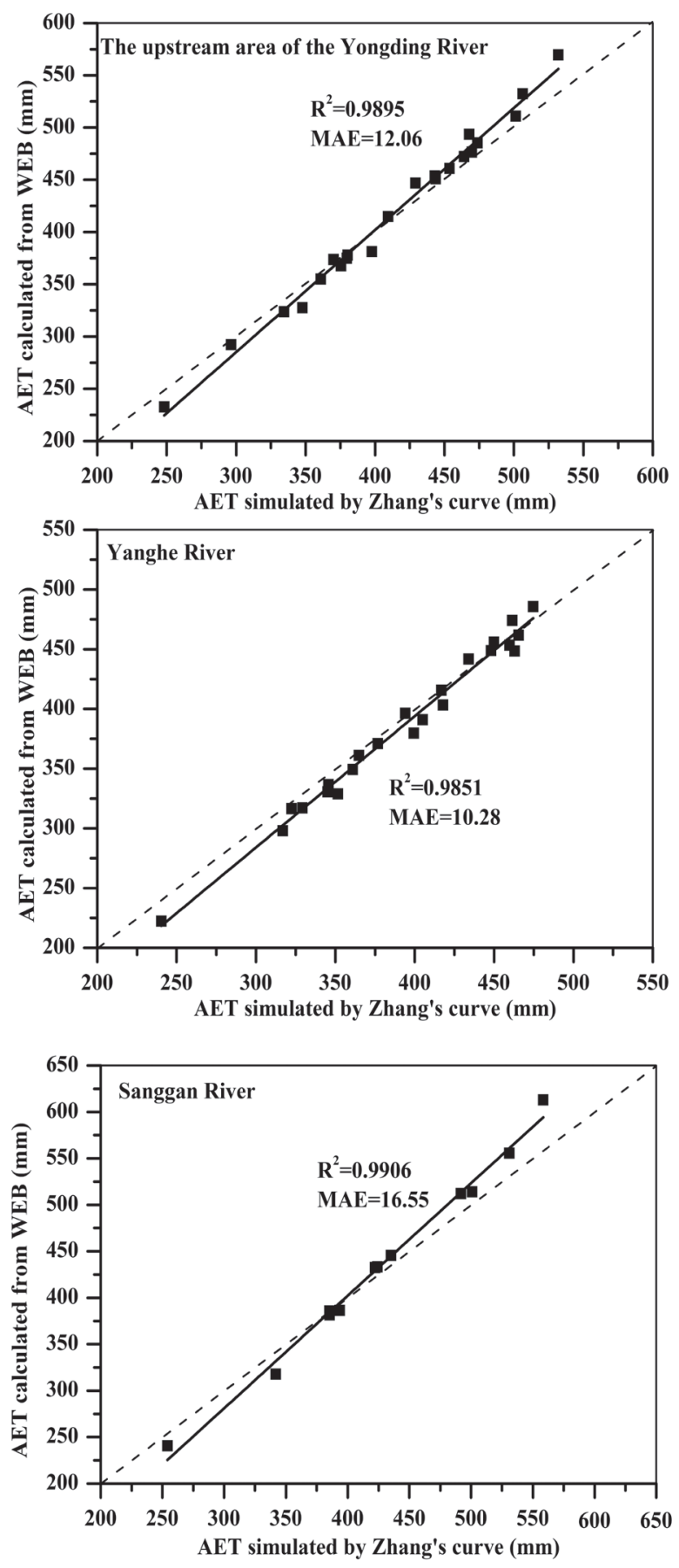

Fig. 5. Correlation relationships between actual annual evapotranspiration (AET) calculated directly from the water balance equation (WBE) and simulated by Zhang's curve for the baseline period. 
Table 5. Effects of climate variability and human activity on the mean annual runoff for the 2 evaluation periods based on the baseline period using the climate elasticity method based on the Budyko hypothesis.

\begin{tabular}{|c|c|c|c|c|}
\hline \multirow{2}{*}{ Basin } & \multicolumn{3}{|c|}{ Contribution proportional to the average annual runoff change (\%) } \\
\cline { 2 - 5 } & \multicolumn{2}{|c|}{ Evaluation period I } & \multicolumn{3}{c|}{ Evaluation period II } \\
\cline { 2 - 5 } & Climate variability & Human activity & Climate variability & Human activity \\
\hline Upstream area of the Yongding River & 34.31 & 75.69 & 26.63 & 73.37 \\
\hline Sanggan River & 18.49 & 81.51 & 27.27 & 72.73 \\
\hline Yanghe River & 17.96 & 82.04 & 22.06 & 77.94 \\
\hline
\end{tabular}

River basin, which was listed nationally as one of 8 key soil and water loss areas in 1983. The first phase of a soil and water loss control project in the upstream area of the Yongding River basin was carried out in 1983. The soil and water conservation measures undertaken upstream of the Yongding River basin included biological measures (e.g., afforestation and grass planting) and engineering measures (e.g., creation of terraces and building warping dams). The first phase of these projects was completed in 1993, and the land utilization rate increased from $48.7 \%$ to $78 \%$, whereas forestry land increased from $9.8 \%$ to $39.6 \%$. The land use/cover changes in the upstream area of the Yongding River were mainly caused by the implementation of ecological restoration campaigns and soil and water conservation measures. Between 1980 and 1995, there were $227 \mathrm{~km}^{2}$ (Sanggan River), 1,294 km² (Yanghe River), and $1,649 \mathrm{~km}^{2}$ (the upstream of Yongding River) increases in the areas of forest land, whereas the areas of farmland decreased by $573 \mathrm{~km}^{2}, 739 \mathrm{~km}^{2}$, and $1,426 \mathrm{~km}^{2}$, respectively. Studies have shown that forest land can reduce runoff through water retention within tree branches and leaves, leaf litter, and root systems. Compared with 1980-1995, land use change was different during 1995-2000, where farmland, grassland (except for the Sanggan River), and developed land increased; forest land, water, and unused land decreased; and the driving factors of runoff change were the increase in industry, agriculture, and domestic water use during this period [20]. Due to forests having the ability to hold water, soil evaporation and evapotranspiration are reduced, and root absorption and evapotranspiration are the weakest. Therefore, when the forest cover area increases, surface runoff yield decreases, but this process also effectively reduces surface evaporation, maintaining soil moisture content and extending the duration of soil moisture [34-35]. Therefore, the increase in forested land in the upstream area of the Yongding River basin leads to a gradual reduction in surface runoff.

\section{Influence on Runoff on Water Conservancy Project Construction}

In the 1950s, building reservoirs had become a primary issue in Shanxi Province. By 1980, 14 largeand medium-sized reservoirs were built in the upstream area of the Yongding River basin, and the total capacity was 5.28 billion $\mathrm{m}^{3}$. Although construction of water conservation facilities played an important role in defending against floods and ensuring the safety of industrial and agricultural production and people's lives and property, the facilities could change the time and spatial distribution of runoff [36]. In dry years, water conservation projects made the runoff increase, with a uniform distribution during the year, and a smooth streamflow process. The reservoirs made water levels rise, reduced speeds, and increased water retention times, which caused evaporation and channel leakage to increase and groundwater replenishment from the river to decrease. Fig. 6 demonstrates the analysis of the impacts of runoff distribution during the year - before and after dam construction on the Guanting Reservoir, which shows that runoff after the dam was constructed was significantly higher than runoff before in the nonflood season (between April and June).

During the non-flood season, the increase in water consumption also led to downstream water reduction. The ability to manually control many small- and medium-sized water conservation projects was poor, which resulted in a change in the measured runoff and made the ecological system difficult to restore. Research has shown that the main factors resulting in runoff

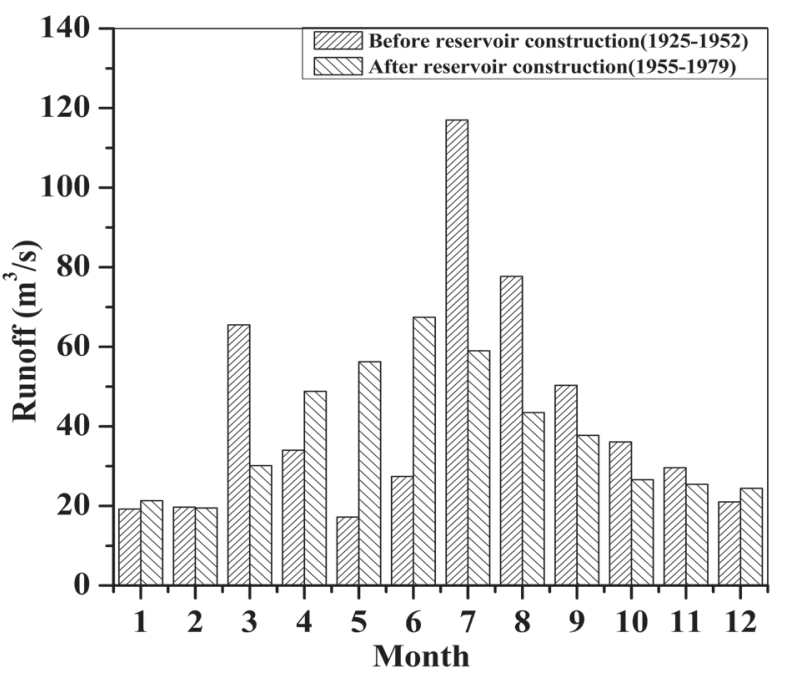

Fig. 6. Comparison of long-term monthly runoff at Guanting Reservoir before and after dam construction. 
change were the construction of the water conservation projects and that the small- and medium-sized reservoirs in particular were the main factors that caused the runoff decreases [37-38].

\section{Effects of Water Withdrawal on Runoff in this Basin}

With social development, the scale of human production and living activities has expanded. The increase in water consumption for economic purposes (which refers to the water resources used by humans in everyday life and other economic activities, including industrial, agricultural, and domestic water consumption) has affected runoff rates, and runoff has exhibited a downward trend.

According to water resource statistics from 2000, the groundwater was approximately 1.75 times that of surface water resources in the upstream area of the Yongding River basin, which is the main source of water supply to the basin. Since the 1970s, groundwater sources have been exploited extensively. The groundwater withdrawal rate was approximately 0.79 billion $\mathrm{m}^{3}$ in 1980, and during 1991-1999 and 2001-2014 the annual averages of groundwater withdrawal were 1.17 billion $\mathrm{m}^{3}$ and 1.29 billion $\mathrm{m}^{3}$, respectively. Because of over pumping deep groundwater, a subsiding centre has formed in the upstream regions (e.g., Zhangjiakou, Datong, Shuozhou) of the Yongding River. The decreasing groundwater levels increased vadose zone thickness, which resulted in the vadose zone absorbing more precipitation, reducing surface water resources [39].

\section{Conclusion}

In this study, we used a climate elasticity method based on the Budyko hypothesis to quantitatively assess the impacts of climate variability and human activities on runoff in the upstream area of the Yongding River basin. The direct expression of human activities is the change in surface conditions within the basin, which changes the evaporation process within the basin (the hydrological cycle). This method has several limitations because it does not consider the interaction between human activities and climate change. The method has a single parameter, $\omega$, which establishes the evaporation area estimation model within a watershed and the underlying surface conditions. Therefore, this method is feasible to use in most areas and could be extended when sufficient data are available.

The impacts of climate change and human activities on runoff changes can consequently be separated by the climate elasticity method based on the assumption that climate and human activities are dominant drivers and are independent factors for runoff change. The results show that human activities are mainly responsible for the runoff reduction in the upstream area of the Yongding River basin. Compared with the contribution of human activities in evaluation period II, the contributions of human activities to runoff change are larger in evaluation period I, which shows that the impact of climate change on runoff increases gradually. The main factors of human activities that affect runoff change in the upstream area of the Yongding River basin include land use/cover change (soil and water conservation measures), water conservation project construction, and increasing water withdrawals resulting from economic and social development. Furthermore, the results of this study can serve as a reference for regional water resource management and planning and provide a practical analysis for local administrative managers to organize local actions and reduce the negative effect of human activities on local water resources.

\section{Acknowlegements}

The paper was funded by the Beijing Natural Science Foundation (China Institute of Water Resources and Hydropower Research, No. Z160001). The author appreciates the anonymous reviewers for their valuable comments and criticisms.

\section{Conflict of Interest}

The authors declare no conflict of interest.

\section{References}

1. ADAMOWSKI K., BOUGADIS J. Detection of trends in annual extreme rainfall. Hydro. Process.17, 3547, 2003.

2. ZHANG S.R., LU X.X. Hydrological responses to precipitation variation and diverse human activities in a mountainous tributary of the lower Xijiang, China. Catena 77 (2), 130, 2009.

3. CHASE K.J., HAJ A.E., REGAN R.S., VIGER R.J. Potential effects of climate change on streamflow for seven watersheds in eastern and central Montana. J. Hydrol.: Regional Studies 7, 69, 2016.

4. HENN B., CLARK M.P., KAVETSKI D., NEWMAN A.J., HURGES M., MCGURK B., LUNDQUIST J.D. Spatiotemporal patterns of precipitation inferred from streamflow observations across the Sierra Nevada mountain range. J. 2016. Hydrol.http://dx.doi.org/10.1016/j. jhydrol.2016.08.009.

5. XU B.F, LIANG J., WU B.S. Trends in Water Runoff and Sediment Load in Selected World's Rivers. In: Advances in Water Resources and Hydraulic Engineering .Springer, Berlin, Heidelberg, 889, 2009.

6. ZHANG Z.X., CHEN X., XU C.Y., YUAN L.F., YONG B., YAN S.F. Evaluating the non-stationary relationship between precipitation and streamflow in nine major basins of China during the past 50 years.J. Hydrol. 409 (1-2), 81, 2011.

7. ZHANG S.L., YANG D.W., YANG H.B., LEI H.M. Analysis of the dominant causes for runoff reduction infive major basins over China during 1960-2010. Advance in Water Science 26 (05), 605, 2015. 
8. ZHAN C.S., JIANG S.S., SUN F.B. JIA Y.W., NIU C.W., YUE W.F. Quantitative contribution of climate change and human activities to runoff changes in the Wei River basin, China.Hydrol. Earth Syst. Sci. 18, 3069, 2014.

9. JIANG S.H., REN L.L., YONG B., SINGH V.P., YANG X.L., YUAN F. Quantifying the effects of climate variability and human activities on runoff from the Laohahe basin in northern China using three different methods.Hydrol. Process.25, 2492, 2011.

10. LI H.Y., ZHANG Y.Q., VAZE J., WANG B.D. Separating effects of vegetation change and climate variability using hydrological modelling and sensitivity-based approaches. J. Hydrol. 420-421, 403-418, 2012.

11. WANG G.S., XIA J., CHEN J. Quantification of effects of climate variations and human activities on runoff by a monthly water balance model: A case study of the Chaobai River basin in northern China. Water Resour. Res. ,45, 2009. W00A11,doi:10.1029/2007wr006768.

12. KONG D.X., MIAO CH.Y., WU J. W., DUAN Q. Y.. Impact assessment of climate change and human activities on net runoff in the Yellow River Basin from 1951 to 2012. Ecological Engineering 91, 566, 2016.

13. WANG S.J., YAN Y.X., MING Y., ZHAO X.K. Quantitative estimation of the impact of precipitation and human activities on runoff change of the Huangfuchuan River Basin.J.Geogr. Sci. 22 (5), 906,. 2012.

14. ZHANG L., KARTHIKEYAN R., BAI ZH.K., SRINIVASAN R. Analysis of streamflow responses to climate variability and land use change in the Loess Plateau region of China. CATENA 154, 1, 2017.

15. WANG W.G., SHAO Q.X., YANG T., PENG S.Z., XING W.Q., SUN F.C., LUO Y.F. Quantitative assessment of the impact of climate variability and human activities on runoff changes: a case study in four catchments of the Haihe River basin, China. Hydrol. Process. 27 (8), 1158, 2013.

16. ZHAO Y.F., ZOU X.Q., GAO J.H., XU X.W.H. WANG C.L., TANG D.H., WANG T., WU X.W. Quantifying the anthropogenic and climatic contributions to changes in water discharge and sediment load into the sea: A case study of the Yangtze River, China.Science of the Total Environment 536, 803, 2015.

17. PERVEZ M.S., HENEBRY G.M. Assessing the impacts of climate and land use and land cover change on the freshwater availability in the Brahmaputra River basin. J. Hydrol.: Regional Studies 3, 285, 2015.

18. NASH L.L., GLEICK P.H. Sensitivity of streamflow in the Colorado Basin to climatic changes.J. Hydrol. 125 (3-4), 221, 1991.

19. DEY P., MISHRA A. Separating the impacts of climate change and human activities on streamflow: A review of methodologies and critical assumptions. J. Hydrol. 548, 278, 2017.

20. DING A.Z, ZHAO Y.J, HAO D., ZHANG S.R., QIAO G.J. Analysis of Variation Characteristics of Runoff and Their Influencing Factors in the Yongding River Basin. South-to-North Water Transfers and Water Science \& Technology 11 (01), 17, 2013.

21. WANG L. Distributed Hydrological Model of Yongding River mountain basin and Surface Water Resources Evaluation. Master's thesis, Water Conservancy Specialty, Tsinghua University, China. 2004.
22. FU Y.C. Watershed water related eco-compensation of restoration Research. PHD thesis, Hydrology \& Water Resources Engineering, China Institute of Water Resource and Hydropower Research,China. 2013.

23. MANN H.B. Nonparametric tests against trend. Econometrica 13 (3), 245, 1945.

24. JIANG T., SU B.D., HARTMANN H. Temporal and spatial trends of precipitation and river flow in the Yangtze River Basin, 1961-2000. Geomorphology 85, 143, 2007.

25. PENG D.Z, QIU L.H., FANG J., ZHANG Z.Y. Quantification of Climate Changes and Human Activities That Impact Runoff in the Taihu Lake Basin, China. Mathematical Problems in Engineering 1, 1, 2016.

26. BUDYKO M.I. Climate and life, Academic Press.New York, CA. 1974.

27. SCHREIBER P. Über die Beziehungen Zwischen dem Niederschlag und der Wasserführung der Flüsse in Mitteleuropa. Meteorol. Z. 21 (10), 441, 1904.

28. OL'DEKOP E.M. On Evaporation from the Surface of River Basins: Transactions on Meteorological Observations, Lur-Evskogo Report.Univ. of Tartu, Tartu, Estonia 1911 [In Russian].

29. PIKE J.G. The Estimation of Annual Runoff from Meteorological Data in a Tropical Climate.J. Hydrol. 2, 116, 1964.

30. FU B.P. On the calculation of the evaporation from land surface. Sci. Atmos. Sinica. 5, 23, 1981.

31. ZHANG L., DAWES W.R., WALKER G.R. Response of mean annual evapotranspiration to vegetation changes at catchment scale.Water Resources Research 37 (3), 701, 2001.

32. ZHANG X.P. Responses of streamflow to land use / cover change in He-Long region, the middle reaches of Yellow River, China. PHD thesis, Research field: Regional soil conservation and its environmental impact, Institute of Soil and Water Conservation,CAS \& MWR. 2007.

33. SCHAAKE J.C. From climate to flow. In: Waggoner, P.E.(Ed.), Climate change and U.S. Water Resource. John Wiley, New York, 177-206.8. 1990.

34. JIN L. Research on the effect of the forest cover on sediment and runoff in Shananxi province. Northwest Water Resource \& Water Engineering 13 (3), 53, 2002.

35. WANG D.Y. The study of responding relation between land utilization/coverage changes and the eco-hydrology in the typical basin of Shiyang River. PHD thesis, Research field: Soil and Water Conservation and Desertification Control, Beijing Forestry University. 2013.

36. LI C.L., SUN X. G., PENG Y., ZHOU H.C. Research of runoff variation impacted by hydraulic projects in Fengman Basin. Sourth-to-North Water Transfers and Water Science \& Technology 11 (4), 79, 2013.

37. DEITCH M.J., MERENLENDER A.M., FEIRER S. Cumulative effects of small reservoirs on streamflow in Northern Coastal California Catchments.Water Resour. Manage. 27, 2013.

38. SUN X.G., PENG Y., ZHOU H.C. Impact of land cover change and hydraulic project on runoff based on SWAT distributed watershed hydrological model. Journal of Water Resources \& Water Engineering 27 (1), 33, 2016.

39. SHAO A.J., HU C.S. Impact of environment change on water resources of Hebei Province. China Rural Water and Hydropower 10, 38, 2002. 